\title{
Squamous Cell Carcinoma of the Breast: A Case Report and Review of Literature
}

\author{
Aliyu $\mathrm{S}^{1}$, Zarami $\mathrm{AB}^{1}$, Uzochi $\mathrm{E}^{1}$, Temitope $\mathrm{SA}^{1}$ and Ningi $\mathrm{AB}^{2 *}$ \\ ${ }^{1}$ Department of Surgery, University of Maiduguri Teaching Hospital, Nigeria \\ ${ }^{2}$ Department of Surgery, Abubakar Tafawa Balewa University, Nigeria \\ *Corresponding author: Ningi AB, Department of Surgery, Abubakar Tafawa Balewa University, Nigeria
}

\section{ARTICLE INFO}

Received: 蔧 July 19, 2021

Published: 蔧 August 02, 2021

Citation: Aliyu S, Zarami AB, Uzochi E, Temitope SA, Ningi AB. Squamous Cell Carcinoma of the Breast: A Case Report and Review of Literature. Biomed J Sci \& Tech Res 37(4)-2021. BJSTR. MS.ID.006035.

Keywords: Squamous Cell Carcinoma; Breast Ductal Metaplasia; Rare Tumour

\begin{abstract}
Background: Despite the variety of epithelial malignancies seen in the breast, primary Squamous Cell Carcinoma (SCC) of the breast is rare. It was often classified as one of the metaplastic carcinomas of the breast, although it can arise denovo from benign cysts in the breast. The reported incidence is less than $0.1 \%$ of all the ductal carcinomata. It has no distinct clinical features and radiological appearances are also unremarkable.
\end{abstract}

Case Report: We managed a 43-year-old housewife at the General Surgery Unit of University of Maiduguri Teaching Hospital Borno State-Nigeria, who presented with an 11-month old left breast lump that developed malignant features 2 months prior to presentation. A diagnostic Ultra Sound Scan revealed a $10 \mathrm{~cm}$ retroareola cystic mass with irregular margins and no colour flow on Doppler interrogation, with a provisional diagnosis of a chronic breast abscess. A Fine Needle Aspiration Cytology was equivocal. A wide local excision with axillary dissection was done and postoperative histopathologic analysis showed a primary squamous cell carcinoma. The resection margins were free and only one lymph node showed metastatic deposit.

Conclusion: Adenocarcinoma of the breast is the most common malignancy in the breast. The absence of primary squamous cells in the breast renders pure squamous cell carcinoma a rarity. The presentation of squamous cell carcinoma could be similar to that of an adenocarcinoma or bears a benign outlook. It is imperative therefore to subject all benign lesions of the breast to pathological analysis after removal.

\section{Introduction}

Globally, breast cancer is the most common malignancy seen in women, responsible for $25 \%$ of all cancers seen [1]. It is surpassed by lung cancer alone in terms of incidence and cancer related mortality and it was reported to be responsible for $6.6 \%$ of all cancer related death in women in 2018 [1]. The overall incidence and cancer related mortality is worse in developing countries. The yearly incidence in West Africa is estimated to be about 33\% of all new cancer cases and it is said to be responsible for $24 \%$ of cancer deaths in 2018 [2]. There is no significant difference in the overall incidence and breast cancer related fatality rate in the different parts of Nigeria. In Ibadan, south-western Nigeria, it is the most prevalent female malignancy; accounting for $40.8 \%$ of all cancers seen at the University College Hospital [3,4]. Reports from Jos, North-central of Nigeria and Kano, North-western Nigeria placed breast cancer as the most common malignancy in women $[5,6]$. A report from Enugu, South-Eastern Nigeria also indicated an incidence of $16.9 \%$ and reports from North-Eastern Nigeria is of the same trend $[7,8]$. The most consistent factor in all the reporting is the noticeable rising trend in Nigeria. This has been attributed to an actual increase in incidence, increased awareness of breast cancer in the populace, and an improvement in access to health care and diagnostic tools $[9,10]$. Also, an upward trend in more aggressive histological types, younger age of occurrence at presentation and the presence of more biologically aggressive histological subtypes and triple negative molecular profile are said to be on the rise in Nigeria [10]. 
All over the world the most reported histological subtype is Invasive Ductal Carcinoma, constituting about 60-80\%, although; a rare report has placed it to be about 50\% [11]. This is similar to reports from Ibadan, south-west of Nigeria. The main histological subtype reported is invasive ductal carcinoma responsible for $89.2 \%$ of the cases [11]. This is the consistent finding in the south western part of the country $[12,13]$. The North-Eastern part of Nigeria where this report is coming from also has similar reporting $[11,14]$. The special types of breast cancer are said to occur at a very infrequent rate than that of the invasive ductal carcinoma. These include invasive lobular carcinoma, mucinous carcinoma, apocrine carcinoma, tubular carcinoma, papillary carcinoma, squamous cell carcinoma and lymphoma. The reported incidence from NorthCentral of Nigeria ranged from $3.9 \%$ to $5 \%$ [15]. The relative rarity of these subtypes is also reported in the South-Eastern [16], NorthEastern and South-Western parts of Nigeria $[17,18]$. Other parts of West Africa and the rest of the world also reported same pattern $[19,20]$.

The squamous Cell Carcinoma of the breast is reported to be less than $0.1 \%$ of all the breast malignancies [21-23]. Its clinical presentation and radiological appearance are said to be unremarkable $[23,24,26]$. The complete metaplasia of ductal epithelium is the most widely reported mode of pathogenesis. $[22,25,27]$. It may arise as a sequelae of squamous metaplasia from chronic irritation, as seen in a chronic breast abscess and in the presence of non-biological breast implants [4]. It may arise from squamous metaplasia of a pre-existing adenocarcinoma of the breast $[23,24,26,28]$. It has been reported to arise from squamous metaplasia in benign lesions such as Epidermoid Cyst and Fibroadenoma [29,30]. It is important to differentiate from histopathological assessment, a primary Squamous Cell Carcinoma (SCC) of the breast from secondaries, either from direct extension from overlying skin or from extra mammary origin. This can be achieved through the exclusion of SCC of the overlying skin of the breast or nipple, secondaries from extra mammary origin, presence of unequivocal dominance (more than $90 \%$ ) of areas with SCC, and the lack of other neoplastic cells of ductal or mesenchymal origin [31]. Immunohistochemical study of the cytokeratin profile of any tumour helps in making this distinction. The presence of diffuse CK7, CK8, CK19 staining and focal Carcino-Embryonic-Antigen positivity favors ductal origin [32-35]. The presence of membranous E-cadherin staining is diagnostic of ductal origin also [36,37]. A positive staining for HMW CK, histologic appearance and lamellar keratin formation are typical of squamous cell origin [36,37].

We present a case of a 43-year old married woman on long term steroid therapy, who developed malignant features in an 11-month old left breast lump 2 months prior to presentation. An initial diagnostic breast USS and Fine Needle Aspiration study were equivocal. A wide local excision was done and the postoperative pathological analysis revealed a primary SCC of the breast. We report the case because of its rarity and for being the first reported case from North-Eastern Nigeria.

\section{Case Report}

A 43-year-old Kanuri woman who resides in Maiduguri-Nigeria. She noticed a painless lump in the retroareolar region of the left breast 11-months ago. It was initially the size of a peanut, grew slowly over 9 months and started growing rapidly in the last two months. It developed a continuous dull aching pain, intermittently relieved with non-opiate analgesics and is currently the size of her fist. There is no ulceration, nodules or orange peel appearance of the overlying skin and the nipple-areolar complex is said to be preserved. There was no preceding history of nipple eczematous rashes, bloody discharge, deviation or retraction. A month prior to presentation, she noticed a painless left axillary mass with no ulceration of the overlying skin or ipsilateral arm swelling. The contralateral breast, axilla, neck and arm are said to be free of masses or swelling. She noticed progressive weight loss, anorexia and easy fatigue 2 months before presentation. There was no history suggestive of visceral, brain or bony metastasis. She attained menarche at the age of 14 years, married at 18 years and had her first child at 30 years. She gave birth to 7 children, breast fed all for an average of 18 months and has never used contraceptive drugs. There is no history of a first or second degree relative with breast malignancy. She was diagnosed with Scleroderma 12 years ago, has been on intermittent steroid, immunosuppressive and cytotoxic drugs for 5 years now.

An anxious young woman was seen with no evidence of physiologic derangement on general physical examination. A $10 * 10$ $\mathrm{cm}$ mass was found in the retroareolar area, non-tender, hard, irregular with well-defined margins. The overlying skin showed peau d'orange and a solitary malignant nodule. There is an obvious nipple retraction and a bloody discharge was notice on expressing all the quadrants of the breast. There is a solitary, $2 * 2 \mathrm{~cm}$, discreet, anterior axillary lymph node. It was not warm or tender, hard and irregular with free intrinsic mobility. The contralateral infra and supraclavicular spaces, contralateral breast and axilla were free. No clinical evidence of distant metastasis was noticed. A provisional clinical diagnosis of left breast mitotic lesion (T3N1Mx) to rule out chronic breast abscess was made.

A diagnostic breast USS with a $5 \mathrm{MHz}$ probe was done. A thickwalled $12 \mathrm{~cm}$ cystic lesion with multiple septations was seen. It has a $3 \mathrm{~cm}$ solid component, with no calcification or increased flow on Doppler interrogation. A fine needle aspiration was done, about 60 mls of straw-coloured fluid was drained and cytological analysis of the aspirate showed suspicious ductal cells. A wide local excision with axillary dissection and immediate breast reconstruction was done. Histopathological analysis showed malignant squamous 
epithelial cells thatare disposed in sheets and nests with focal areas of keratin pearls (Figure 1A). The cells are polygonal with intercellular bridges (Figure 2B). Immunohistochemical staining with HMW Cytokeratin Antibody was positive. Immunohistochemical staining for focal Carcino-embryonic-antigen and E-cadherin was negative. The resection and deep margins are free of tumour and only the enlarged lymph node showed metastatic deposit. No adjuvant chemotherapy or radiotherapy given. Immunohistochemical study of molecular profile showed positivity for oestrogen only, progesterone receptor was negative and there is no over expression of the Her2-Neu receptor. Patient is currently on adjuvant selective oestrogen receptor modulator (Tamoxifen) at $20 \mathrm{mg}$ daily for a two and a half years and will be subsequently switched to an Aromatase inhibitor (Anastrazole) for the same duration. Patient is to continue with follow-up visits to the surgical-out-patient-department. An informed consent was obtained from the patient for publication of the case report.

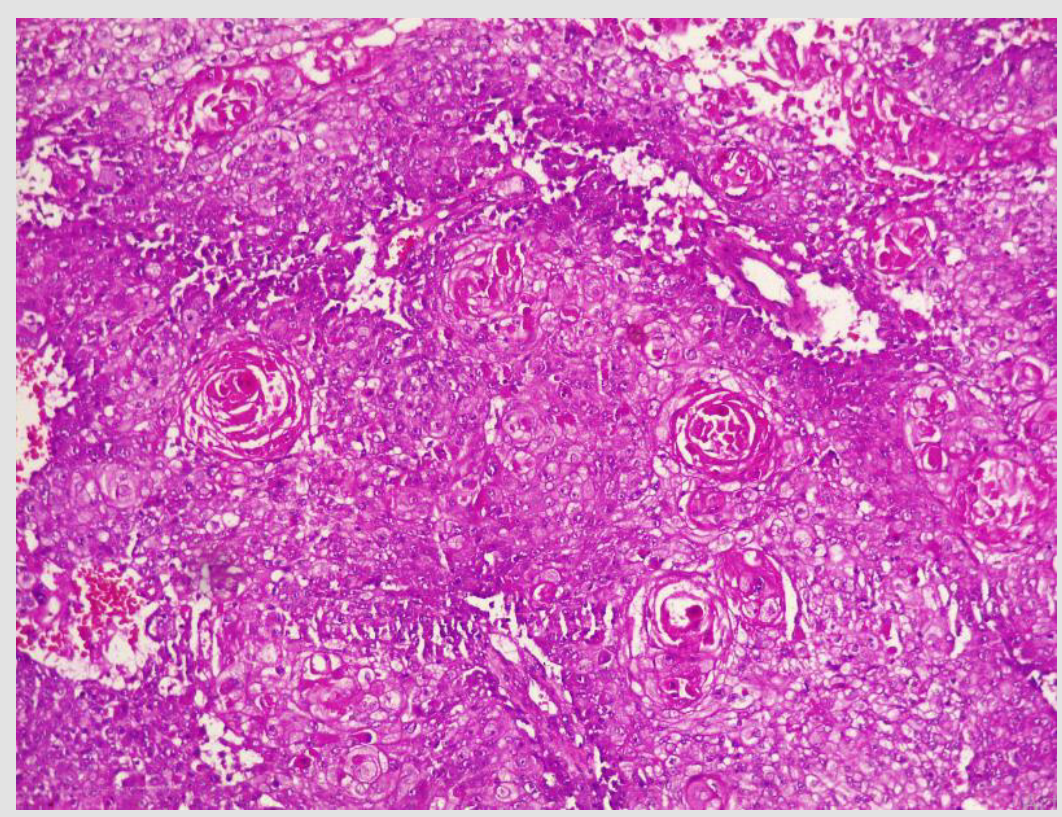

Figure 1: Photomicrographs of malignant squamous epithelial neoplasm that are disposed in sheets with focal areas of keratin pearls $(\mathrm{A}), \mathrm{A}=\mathrm{X} 100$.

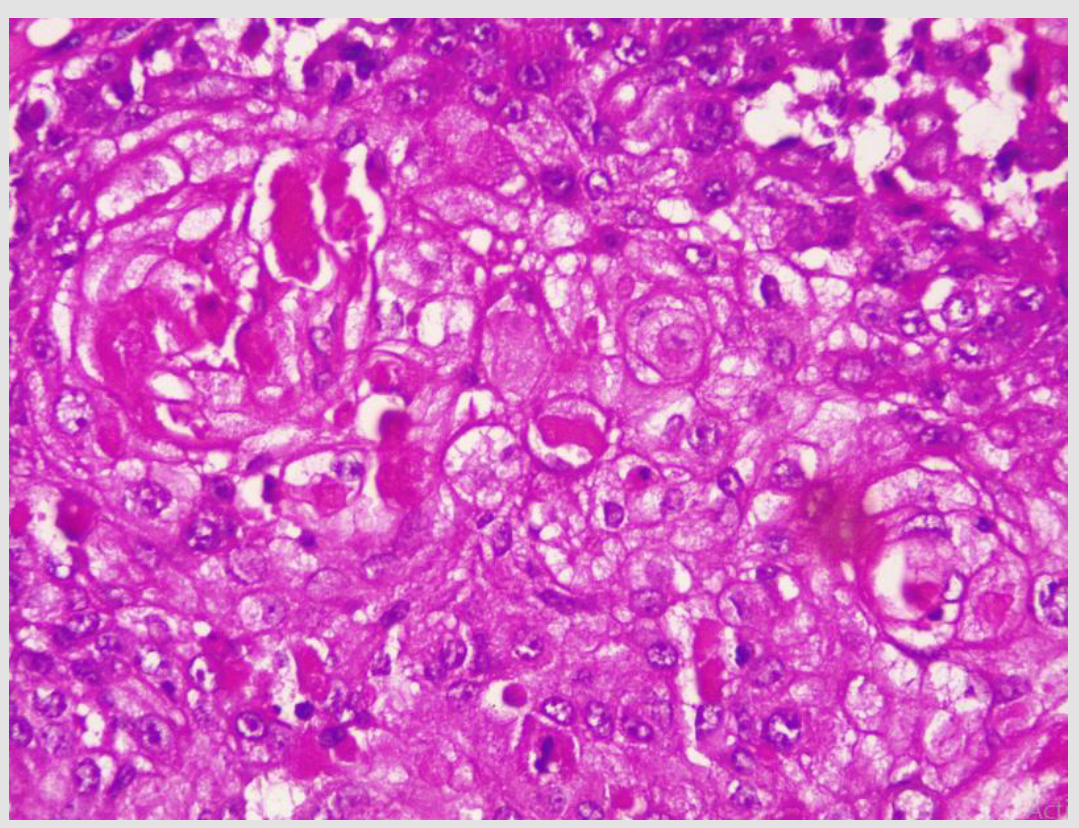

Figure 2: The cells are polygonal with intercellular bridges (B); H and E stained, B=X200. 


\section{Discussion}

There is no consensus on the origin of squamous cell carcinoma, whether it is a pure form of squamous cell carcinoma or it represents an extreme squamous metaplasia of an existing adenocarcinoma [39]. It is thus classified in to primary pure SCC, like our reported case and a mixed type (Figures 1 and 2). The primary pure SCC is characterised by the following features: The predominance $(>90 \%)$ of malignant cells being of the squamous cell type, having no direct relation with the overlying skin of the breast, nipple and the areola, and the absence of evidence for a primary in an extra mammary site $[40,41]$. The mixed type is seen following a squamous metaplasia of an existing adenocarcinoma or a metastasis from an extra mammary origin [42]. The primary Squamous cell metaplasia is known to occur in benign epidermoid, dermoid and sebaceous cysts of the breast [43], as seen in our patient. It may arise within a long standing Fibroadenoma [44]. Primary squamous cell carcinoma of the breast has been observed to arise from squamous metaplasia of ductal epithelium in benign disorders of the breast, such as chronic abscess, after implantation of breast prosthesis and after radiation therapy [45-49]. Although there was USS evidence of a cystic mass in our patient, there was no history suggestive of chronic inflammation, use of implant for breast reconstruction or administration of therapeutic ionizing radiation.

The reported age of high incidence was the 5th -6th decades of life, with an average age of 50 years [50]. Our patient presented at the age of 43 years, almost a decade younger than the age in developed countries. The average age at presentation is 37.3 years in Enugu, south-eastern Nigeria [50]. Like the frequently seen adenocarcinoma, squamous cell carcinoma of the breast is also predominantly seen in post-menopausal women worldwide [4], but, some pockets of studies have reported seeing SCC in women within their gestational or lactating periods [23,32,51]. The decade age gap in the age of occurrence of SCC between women of Africa and those in Europe and North America has been observed by several authors in Nigeria and the sub Saharan Africa. The mean age of the patients at Calabar, South-South of Nigeria was 45.06 years, with an age range of 23 to 76 years [52]. This is similar to reports of the common age of 31-40 years in Lagos, South Western Nigeria [53], 40-49 years in Maiduguri, North Eastern Nigeria [54], and 40-49 years in Ghana, West Africa [55]. The reported ages in developed countries are 40-50 years in Hong Kong, 75-85 years in Maryland-USA and a median age of 62 years for all the histological subtypes [56].

Majority of patients with SCC present with a breast lump, usually a solid mass [25,57], but a significant proportion present with a fluctuant cystic mass, mostly a malignant epidermoid or sebaceous cyst or even a chronic breast abscess with a solid malignant component [58-61]. Our patient presented with a complex mass consisting of both solid and cystic components, probably a benign breast cyst with subsequent squamous metaplasia. Majority of SCC of the breast are said to be biologically aggressive, characterized by rapid growth over short duration and subsequent cystic and necrotic degeneration $[28,60,61]$. The index patient noticed such rapid growth with associated nodule formation just 2 months prior to presentation. Like mucinous adenocarcinoma, Squamous cell carcinoma of the breast is reported to be bulky, most often measuring greater than $5 \mathrm{~cm}$ (T3) in its widest dimension $[59,60,61]$. Our index mass measured $10 \mathrm{~cm}$ in its widest diameter. Many reports have indicated the preponderance of the left breast as the site of squamous carcinoma more than the right [43]. Our patient also presented with a left breast mass. Wynder et al. have reported the tendency for left-sided preponderance of the carcinoma of the breast of all types.

No identifiable risk factors were noted in the index patient, except for the age, presence of a breast cystic mass and long term steroid therapy. It has been noted above that most SCC in the African women are seen in the 4th decade of life [52-55], just like the age of 43 years at presentation for our patient. The presence of a cystic mass also reinforced the suspicion of a squamous metaplasia of the epithelium on the cyst wall, as reported by many authors $[58,59]$. The use of steroid and immunosuppressive drugs for more than 10 years could have impaired the body's ability for immunologic surveillance, to arrest progression from dysplastic state and to halt lymphatic metastasis. Our patient presented with a clinically palpable ipsilateral axillary lymph node that showed positive metastasis on histology. Surprisingly, most reports indicated that Squamous cell carcinomas do not readily metastasize through the lymphatics like the adenocarcinomas. In fact, in only $10-30 \%$ of cases is lymph node involvement encountered intra-operatively $[26,42,45]$. However, up to $30 \%$ of the patients may harbour distant metastases at the time of presentation $[26,42]$.

A diagnostic breast USS with a $5 \mathrm{MHz}$ probe was done. A thickwalled $12 \mathrm{~cm}$ cystic lesion with multiple septations was seen. It has a $3 \mathrm{~cm}$ solid component, with no calcification or increased flow on Doppler interrogation. Other authors have reported also that there are no typical findings on the mammogram and a breast USS may only reveal a complex cystic mass with solid component or an inflammatory process [42]. Calcification and Cystic changes are often the frequent radiological finding [24-26,58]. A fine needle aspiration was done, about $60 \mathrm{mls}$ of straw-coloured fluid was drained and cytological analysis of the aspirate showed suspicious ductal cells. A Tru-cut biopsy is the preferred method of obtaining a pathological diagnosis, as fine needle aspiration study is often not helpful [42]. In a study done by Gupta RK et al, very few patients have the histological diagnosis confirmed via a fine needle aspiration 
$[62,63]$. A wide local excision with axillary dissection and immediate breast reconstruction was done. Histopathological analysis showed malignant squamous epithelial neoplasm that are disposed in sheets and nests with focal areas of keratin pearls (Figure 1A). The cells are polygonal with intercellular bridges (Figure 2B). The reported histological evidence of a primary SCC of the breast is the microscopic appearance of malignant cells composed of infiltrative nests of atypical epithelial cells with irregular and hyperchromatic nuclei. There may be variable amounts of keratinous lamellar or a pseudo-sarcomatoid stroma [64-68]. It may have associated Ductal Carcinoma In-Situ or squamous metaplasia of ductal epithelium at the periphery of the invasive carcinoma $[23,25,26,59,69]$. Immunohistochemical staining with HMW Cytokeratin was positive. immunohistochemical staining for focal Carcinoembryonic-antigen and E-cadherin was negative. For adequate treatment, it is imperative to separate cutaneous SCC from primary SCC of the breast. Apart from the requirement of the predominance $(>90 \%)$ of the squamous malignant cells in all the arrears of the tumour, the tumour should have no continuity with overlying epidermis or dermal appendages [31]. Immunohistochemical staining has emerged as an important diagnostic tool in making such distinction. Both the pure primary SCC of the breast and the SCC extending in to breast parenchyma from overlying skin stain positive with HMW-CK antibody. But, only primary pure SCC shows diffuse positive staining for CK 7, CK 8 and CK19 Antibodies [3336]. The distinction of pure primary SCC from secondary SCC from extra mammary sites such as the lungs is also difficult, because SCC differentiation demonstrate identical immunohistochemical staining in every organ in the body [21]. The demonstration of MAP2K4 gene mutation in a biopsied specimen should confirm an extra mammary origin, especially a lung SCC $[21,70]$.

The resection and deep margins are free of tumour and only the enlarged lymph node showed metastatic deposit. No adjuvant chemotherapy or radiotherapy given. Literature review has shown that surgery is the mainstay of the treatment and a definitive role for adjuvant therapy has not been determined [24-26, 57 59]. Both adjuvant radiotherapy and chemotherapy have been used with variable outcomes [24,26,47,57]. Majority of reports did not demonstrate a superior oncologic outcome with the use of adjuvant radiotherapy in primary SCC of the breast in stark contrast to extra mammary primary SCC $[28,71]$. Some studies have demonstrated an objective response and subsequent down staging of locally advanced pure primary SCC of the breast with the use of combined Neoadjuvant chemotherapy and radiotherapy $[57,58]$. Immunohistochemical study for molecular profile showed positivity for oestrogen only and progesterone receptor was negative, with no over expression of the Her2-Neu receptor. Patient is currently on adjuvant selective oestrogen receptor modulator (Tamoxifen) at 20 mg daily for two and a half years and will be subsequently switched to an Aromatase inhibitor for the same duration. The pure primary Squamous cell carcinomas are known to be mostly hormone receptor negative $[40,41,46]$. The over expression of c-erbB-2 is also usually not seen, but, some few reports have indicated an overexpression $[69,72]$. Patient is to continue with follow-up visits to the surgical-out-patient-department.

Because of its rarity, no much data has been published concerning the disease free survival and overall survival after curative treatment. A single-centre, small sample-size, retrospective study reported a 5-year survival of $67 \%$ in [26]. Menville has reported that prognosis is dependent upon the tumour biology and grade and may vary between deaths within 4 months in metastatic disease, to 16 years in early disease with curative resection [29]. Although the clinical course and prognosis of the SCC of the breast have remained obscure, many reports have considered a young age below 40 years, large tumour size and a histologically proven nodal metastasis to be markers of poor prognosis $[25,26,57,71]$.

\section{Conclusion}

Despite its rarity, a primary squamous cell carcinoma of the breast is of clinical significance, because it can masquerade as a benign mass or arise within an existing adenocarcinoma. It's often high histological grade, lack of hormone receptor positivity and often poor response to adjuvant care make its treatment herculean. Every benign breast mass removed must be subjected to pathological analysis, especially chronic cysts and abscesses.

\section{Authors' Contribution}

Aliyu S and Ningi AB co-wrote the paper and together with UZOCHI E and TEMITOPE SA took part in the care of the patient. $\mathrm{AB}$ Zarami helped in preparation and examination of the specimen.

\section{References}

1. Bray F, Ferlay J, Soerjomataram I, Siegel RL, Torre LA, et al. (2018) Global cancer statistics 2018: GLOBOCAN estimates of incidence and mortality worldwide for 36 cancers in 185 countries. CA Cancer J Clin 68(6): 394424.

2. Global Cancer Facts \& Figures. Atlanta: American Cancer Society.

3. Ferlay J, Soerjomataram I, Dikshit R, Eser S, Mathers C, et al. (2015) Cancer incidence and mortality worldwide: sources, methods and major patterns in GLOBOCAN 2012. Int J Cancer 136(5): E359-E386.

4. Jedy-Agba E, Curado MP, Ogunbiyi O, Oga E, Fabowale T, et al. (2012) Cancer incidence in Nigeria: a report from population-based cancer registries. Cancer Epidemiol 36(5): e271-e278.

5. Mandong BM, Madaki AKJ, Manasseh AN (2003) Malignant diseases in Jos: A follow up. Ann Afr Med 2(2): 49-53.

6. Yusuf I, Atanda AT, Umar AB, Imam MI, Mohammed AZ, et al. (2017) Cancer in Kano, North-western Nigeria: a 10-year update of the Kano cancer registry. Ann Trop Pathol 8(2): 87-93.

7. Njeze GE (2014) Breast lumps: a 21-year single-center clinical and histological analysis. Niger J Surg 20(1): 38-41. 
8. Nggada HA, Yawe K-DT, Abdulazeez J, Khalil MA (2008) Breast cancer burden in Maiduguri, North Eastern Nigeria. Breast J 14(3): 284-286.

9. Ozoilo KN, Misauno MA, Chukwuogo O, Ozoilo JU, Ojo EO, et al. (2014) Breast cancer screening in a resource-poor setting: A preliminary report. J Med Trop 16(1): 14-18.

10. Azubuike So, Muirhead C, Hayes L, McNally R (2018) Rising global burden of breast cancer: the case of sub-Saharan Africa (with emphasis on Nigeria) and implications for regional development: A review. World J Surg Oncol 16(1): 63.

11. Halperin EC, Wazer DE, Perez CA, Brady LW (2008) Perez and Brady's Principles and Practice of Radiation Oncology. In: Lippincott Williams \& Wilkins, ( $5^{\text {th }}$ edn.). Philadelphia, pp. 892-912.

12. Adesunkanmi ARK, Lawal 00, Adelusola KA, Durosimi MA (2006) The severity, outcome and challenges of breast cancer in Nigeria. Breast 15(3): 399-409.

13. Ayandipo 00, Ogun GO, Adepoju OJ, Fatunla EO, Afolabi AO, et al. (2020) Impact of axillary node-positivity and surgical resection margins on survival of women treated for breast cancer in Ibadan, Nigeria. Ecancermedicalscience 14: 1084.

14. Dauda AM, Misauno MA, Ojo EO (2011) Histopathological types of breast cancer in Gombe, North Eastern Nigeria: a seven-year review. Afr J Reprod Health 15(1): 109-111.

15. Vhriterhire AR, Akpor OI, Ngbea AJ, Ojo AB, Eke AB, et al. (2019) Breast Cancer Histological Pattern in Makurdi, Nigeria. J Res in Basic \& Clin Sci 1 (4): 297-302.

16. Ebughe GA, Ugare GU, Nnoli MA, Bassey IA, Nwagbara VJ, et al. (2013) Histological type and tumour grade in Nigerian breast cancer: relationship to menarche, family history of breast cancer, parity, age at first birth, and age at menopause. IOSR J Dent Med Sci 7(5): 58-63.

17. Nggada HA, Gali BM, Bakari AA, Yawe-Terna EH, Tahir MB, et al. (2011) The spectrum of female breast diseases among Nigerian population in Sahel climatic zone. J Med Sci 2(10): 1157-1161.

18. Ntekim AI, Folasire AM, and Ali-Gombe M (2019) Survival pattern of rare histological types of breast cancer in a Nigerian Institution. Pan Afr Med J 34: 114 .

19. Quayson SE, Wiredu EK, Adjei DN, Anim JT (2014) Breast cancer in Accra, Ghana. J Med Biomed Sci 3(3): 21-26.

20. Gudavičlenė D, Steponavičlenè L, MešKauskas R, Smailyte G, Aleknavicius E (2012) Rare types of breast carcinoma. Acta medica Lituanica 19(2): 81-91.

21. Vollmer RT (2009) Primary lung cancer vs. metastatic breast cancer: A probabilistic approach. Am J Clin Pathol 132(3): 391-395.

22. Tavassoli FA (1999) Infiltrating carcinoma: special types. In: Tavassoli FA, (Ed), Pathology of the breast ( $2^{\text {nd }}$ edn.). Stamford, CT: Appleton \& Lange, pp. 481-570.

23. O’Malley FP, Pinder SE (2006) Invasive carcinoma: special types. In: Harris GC, Pinder SE, O'Malley FP, (Eds). Philadelphia, PA: Churchill Livingstone, $1^{\text {st }}$ edn. Breast pathology pp. 201-223.

24. Hennessy BT, Krishnamurthy S, Giordano S, Buchholz TA, Kau SW, et al. (2005) Squamous cell carcinoma of the breast. J Clin Oncol 23: 7827 7835 .

25. Cardoso F, Leal C, Meira A, Azevedo R, Mauricio MJ, et al. (2000) Squamous cell carcinoma of the breast. Breast 9: 315-319.

26. Behranwala KA, Nasiri N, Abdullah N, Trott PA, Gui GP (2003) Squamous cell carcinoma of the breast: clinico-pathologic implications and outcome. Eur J Surg Oncol 29 (4): 386-389.
27. Tan YM, Yeo A, Chia KH, Wong CY (2002) Breast abscess as the initial presentation of squamous cell carcinoma of the breast. Eur J Surg Oncol 28(1): 91-93.

28. Miura H, Taira O, Hiraguri S, Maeda J, Kato H (2002) Recurrent squamous cell carcinoma of the breast with undifferentiated features: report of a case. Surg Today 32: 891-895.

29. Menville JG (1936) Simple dermoid cysts of the breast. Ann Surg 103(1): 49-56.

30. Salm R (1957) Epidermoid metaplasia in mammary fibro-adenoma with formation of keratin cysts. J Pathol 74: 221-222.

31. Peyker T, Ali Rıza K, Gülin Ș, Teoman C, Cihan G (2010) Primary squamous cell carcinoma of the breast: a case report and immunohistochemically features for differential diagnosis. Trakya Univ Tip Fak Derg 27(2): 198202.

32. Aparicio I, Martínez A, Hernández G, Hardisson D, De Santiago J (2008) Squamous cell carcinoma of the breast. Eur J Obstet Gynecol Reprod Biol 137(2): 222-226.

33. Megha T, D’Amuri A, Benvenuto A, De Santi MM, De Luca, et al. (2004) Primary squamous cell carcinoma of the breast: a case report. Pathologica 96: 45-48.

34. Ciocca V, Bombonati A, Gatalica Z, Di Pasquale M, Milos A, et al. (2006) Cytokeratin profiles of male breast cancers. Histopathology 49(5): 365370 .

35. Abd El-Rehim DM, Pinder SE, Paish CE, Bell J, Blamey RW, et al. (2004) Expression of luminal and basal cytokeratins in human breast carcinoma. J Pathol 203(2): 661-671.

36. Gal-Gombos EC, Esserman LE, Recine MA, Poppiti RJ Jr (2002) Largeneedle core biopsy in atypical intraductal epithelial hyperplasia including immunohistochemical expression of high molecular weight cytokeratin: analysis of results of a single institution. Breast J 8(2): 269274 .

37. Bratthauer GL, Wheeler DT, Tavassoli FA (2008) The ductal phenotypic expression of the E-cadherin/catenin complex in tubulolobular carcinoma of the breast: an immunohistochemical and Clinicopathologic study. Mod Pathol 21(8): 1058.

38. Choi YJ, Pinto MM, Hao L, Riba AK (2008) Interobserver variability and aberrant E-cadherin immunostaining of lobular neoplasia and infiltrating lobular carcinoma. Mod Pathol 21(10): 1224-1237.

39. Karma HT, Gadgil PA, Chaware SA, Kanade UA (2011) Acantholytic variant of squamous cell carcinoma of the breast: a rare case report. Ecancermedicalscience 5: 214.

40. Siegelmann-Danieli N, Murphy TJ, Meschter SC, Stein ME, Prichard J (2005) Primary pure squamous cell carcinoma of the breast. Clin Breast Cancer 6(3): 270-272.

41. Zoltan TB, Konick L, Coleman RJ (2001) Pure squamous cell carcinoma of the breast in a patient with previous adenocarcinoma of the breast: a case report and review of the literature. Am Surg 67(7): 671-673.

42. Elvira RF, Mans H, Mike SL (2008) Squamous cell carcinoma of the breast: a case report. World J Sur Onc 6:135.

43. Hasleton PS, Misch KA, Vasudev KS, George D (1978) Squamous carcinoma of the breast. J Clin Pathol 31(2): 116-124.

44. Johnson R, Lawrence TW (1917) Two cases of squamous epithelial tumour of the breast. British J Surg 5(19): 417-421.

45. Gupta G, Malani AK, Weigand RT, Rangenini G (2006) Pure primary squamous cell carcinoma of the breast: A rare presentation and Clinicopathologic comparison with usual ductal carcinoma of the breast. Pathol Res Pract 202(6): 465-469. 
46. Wrightson WR, Edwards MJ, McMasters KM (1999) Primary squamous cell carcinoma of the breast presenting as a breast abscess. Am Surg 65(12): 1153-1155.

47. Tan YM, Yeo A, Chia KH, Wong CY (2002) Breast abscess as the initial presentation of squamous cell carcinoma of the breast. Eur J Surg Oncol 28(1): 91-93.

48. Talmor M, Rothaus KO, Shannahan E, Cortese AF, Hoffman LA (1995) Squamous cell carcinoma of the breast after augmentation with liquid silicone injection. Ann Plast Surg 34(6): 619-623.

49. Singh H, Williams SP, Kinsella V, Lynch GR (2000) Postradiation squamous cell cancer of the breast. Cancer Invest 18(4): 343-346.

50. Wilson IO (2017) Squamous cell carcinoma of the breast in a developing community. Int J Cell Sci Mol Biol 1(3): 555565.

51. Rokutanda N, Iino Y, Yokoe T, Maemura M, Horiguchi J, et al. (2000) Primary squamous cell carcinoma of the breast during lactation: a case report. Jpn J Clin Oncol 2000; 30(6): 279-282.

52. Godwin AE, Gabriel UU, Martin AN, Ima-Abasi B, Victor J, et al. (2013) Histological type and tumour grade in nigerian breast cancer: relationship to menarche, family history of breast cancer, parity, age at first birth, and age at menopause. IOSR J Dental Med Sci 7(5): 58-63.

53. Jeje EA, Mofikoya BO, Oku YE (2010) Pattern of breast masses in Lagos: a private health facility review of 189 consecutive patients. Nig Q J Hosp Med 20(1): 38-41.

54. Nggada HA, Yawe KD, Abdulazeez J, Khalil MA (2008) Breast cancer burden in Maiduguri, North eastern Nigeria. Breast J 14(3): 284-286.

55. Clegg-Lamptey J, Hodasi WA (2007) A study of breast cancer in korle bu teaching hospital: assessing the impact of health education. Ghana Med J 41(2): 72-77.

56. Anderson WF, Pfeiffer RM, Dores GM, Sherman ME (2006) Comparison of age distribution patterns for different histopathologic types of breast carcinoma. Cancer Epidemiol Biomarkers Prev 15(10): 1899-1905.

57. Menes T, Schachter J, Morgenstern S, Fenig E, Lurie H, et al. (2003) Primary squamous cell carcinoma (SqCC) of the breast. Am J Clin Oncol 26(6): 571-573.

58. Moisidis E, Ahmed S, Carmalt H, Gillett D (2002) Primary squamous cell carcinoma of the breast. ANZ J Surg 72 (1): 65-67.

\section{ISSN: 2574-1241}

DOI: 10.26717/BJSTR.2021.37.006035

Ningi AB. Biomed J Sci \& Tech Res

(C) (P) This work is licensed under Creative

Commons Attribution 4.0 License

Submission Link: https://biomedres.us/submit-manuscript.php
59. Shigekawa T, Tsuda H, Sato K, Ueda S, Asakawa H, et al. (2007) Squamous cell carcinoma of the breast in the form of an intracystic tumour. Breast Cancer 14(1): 109-112.

60. Yashar P, Sepahdari AR, Mahjoubi FD (2006) Primary squamous cell carcinoma of the breast in an adult woman. Breast J 12(6): 571-572.

61. Gupta C, Malani AK (2006) Abscess as initial presentation of pure primary squamous cell carcinoma of the breast. Clin Breast Cancer 7(2): 180.

62. Wynder EL, Bross IJ, Hirayama T (1960) A study of the epidemiology of cancer of the breast. Cancer 13: 559-601.

63. Gupta RK, Dowle CS (1997) Cytodiagnosis of pure primary squamouscell carcinoma of the breast by fine-needle aspiration cytologie. Diagn Cytopathol 17(3): 197-199.

64. Jones EL (1969) Primary squamous-cell carcinoma of breast with pseudosarcomatous stroma. J Pathol 97: 383-385.

65. McDevitt RW, Stewart FW, Berg JW (1968) Tumours of the Breast. In: Atlas of Tumour Pathology, $2^{\text {nd }}$ series, fasc 2, pp. 95. Armed Forces Institute of Pathology. Washington DC, USA.

66. Cornes JS, Lewis MS (1966) Polypoid carcinoma of the pharynx with sarcomatous or pseudosarcomatous stroma. Br J Surg 53(4): 340-344.

67. Cornog JL, Mobini J, Steiger E, Enterline HT (1971) Squamous carcinoma of the breast. Am J Clin Pathol 55(4): 410-417.

68. Saphir 0, Vass A (1938) Carcinosarcoma. Am J Cancer 33: 331-361.

69. Karamouzis MV, Fida A, Apostolikas N, Rigatos G (2006) A case of HER$2(+)$ squamous cell breast carcinoma: an unusual presentation of an unusual clinical entity. Eur J Surg Oncol 32(10): 1250-1251.

70. Telli ML, Gradishar WJ, Ward JH (2019) NCCN Guidelines updates: breast cancer. J Natl Compr Cancer Netw 17(5.5): 552-555.

71. Rayson D, Adjei AA, Suman VJ, Wold LE, Ingle JN (1999) Metaplastic breast cancer: prognosis and response to systemic therapy. Ann Oncol 10(4): 413-419.

72. Reis-Filho JS, Milanezi F, Steele D, Savage K, Simpson PT, et al. (2006) Metaplastic breast carcinomas are basal-like tumours. Histopathology 49(1): 10-21.

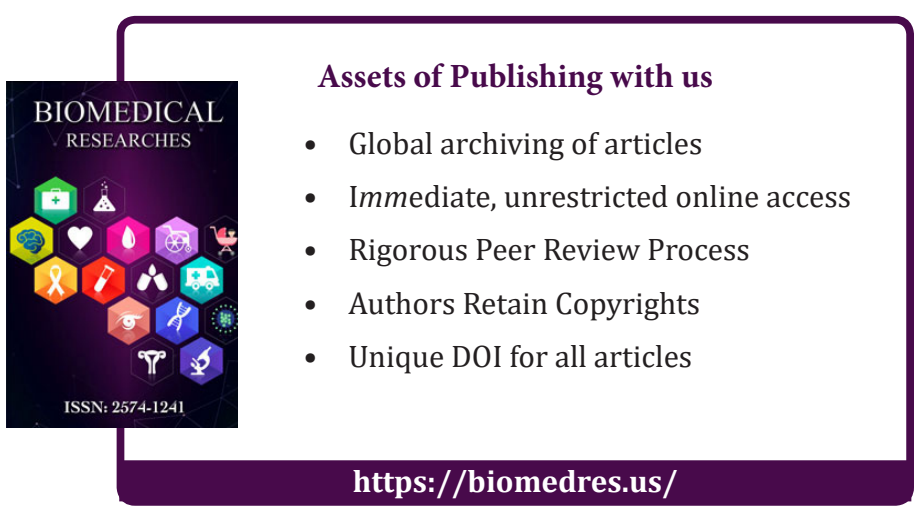

